mission of air to the lungs. The vaso-dilator nerve centres (sudorific and respiratory) are excited directly by superheated blood.

AN interesting trial of an electrically-moved tramcar took place on Monday at Kew, and, notwithstanding some inevitable hitches, may be regarded as fairly successful. The peculiarity of the application of electricity in the present case lies in the use made of accumulators. The car was constructed at the Electrical Power Storage Company's works at Millwall, and is of the usual dimensions for carrying forty-six inside and outside passengers. It weighs, with its accumulators and machinery, but without any passengers, four and a half tons. Under the inside seats of this tramcar is placed the accumulator, consisting of fifty Faure-Sellon-Volckmar cells, each measuring $\mathrm{r}_{3}$ inches by $\mathrm{II}$ inches by 7 inches, and each weighing about $80 \mathrm{lbs}$. This accumulator, when fully charged, is capable of working the tramear with its maximum load for seven hours, which means half a day of tramway service. From the accumulators the current is communicated by insulated wire to a Siemens' dynamo placed underneath the car, which acts as a motor, the motion being transmitted to the axle of the wheels through a driving-belt. To start the car the current is switched on from the accumulator to the dynamo, the armature of which being set in motion, the power is communicated to the driving wheels. The car can be driven from either end, and the power required can be exactly apporioned to the work to be done by using a greater or lesser number of cells. On a level road, for instance, with a light load, only a comparatively small number of cells will be necessary, but with a heavy load or on a rising gradient greater power will be required, and additional cells must be switched in. The action of the motor, and consequently the direction of the car, can be readily. reversed by reversing the current, and the car can also be as readily stopped by shutting off the current entirely and applying the handbrake with which the car is fitted. At night the car is lighted by means of four Swan incandescent lamps, two of which are placed under the roof and one at each end of the car. All the lamps derive their current from the accumulator. The car is also fitted with electric bells, worked from the same source, and is to be run regularly on the Acton tramway line. The Storage Company also had a successful trial on Monday at Kew of a launch fitted with a battery of forty cells and a Siemens' dynamo.

WE learn from the last number of the Fournal of the Russian Chemical and Physical Society (1883, fascicule I) that, at a recent meeting of the Society, Prof. Mendeléeff made a communication on the applicability of the third law of Newton to the mechanical explanation of chemical substitutions, and especially to the expression of the structure of hydrocarbons. If we admit not only the substitution of hydrogen by methyl, but also the substitution of $\mathrm{CH}_{2}$ by $\mathrm{H}_{2}$, and of $\mathrm{CH}$ by $\mathrm{H}_{3}$-as must be according to the law of substitutions as deduced from the third law of Newton-we can not only explain, but also predict, all cases of isomerism, without recurring to the usual conceptions as to the connections and atomicities of elements. Thus, benzene can be understood as a normal butane, $\mathrm{CH}_{3} \mathrm{CH}_{2} \mathrm{CH}_{2} \mathrm{CH}_{3}$, or $\left(\mathrm{CH}_{3} \mathrm{CH}_{2}\right)_{2}$, where a double symmetrical substitution of $\mathrm{H}_{3}$ by $\mathrm{CH}$ has taken place, the $\mathrm{H}_{2}$ having been taken from $\mathrm{CH}_{3}$ and the third $\mathrm{H}$ from $\mathrm{CH}_{2}$, so that only the $\mathrm{CH}$ groups are left; benzene being thus $=\left(\begin{array}{c}\mathrm{CHCH} \\ \mathrm{CH}\end{array}\right)^{2}$. It would explain the isomer of benzene, diproparzyl the formation from acetylene, and the substitution and addition products from benzene.

THE additions to the Zoological Society's Gardens during the past week include a Rhesus Monkey (Macacus erythrous of) from India, presented by Mr. C. F. Henshaw; a Grey Ichneu- mon (Herpestes griseus) from India, presented by Mr. F. C. H. Dadswell; a Herring Gull (Larus argentatus), British, presented by Miss Ella Vicars; three Common Swans (Cygnus olor), British, presented by Mr. J. Hargreaves; four Prairie Grouse (Tetrao cupido) from Iowa, North America, presented by Mr. Henry Nash; a Daubenton's Curassow (Crax daubentoni o) from Venezuela, presented by Mr. Rowland Ward, F.Z.S.; a North American Turkey (Meleagris gallo-pavo of) from North America, presented by His Grace the Duke of Argyll, K.T., F.R.S. ; a Malbrouck Monkey (Cercopithecus cynosurus) from West Africa, deposited; a Gaimard's Rat Kangaroo (Hypsiprymmus gaimardi $\$$ ), three Coypu Rats (Myopotamus coypus), born in the Gardens.

\section{GEOGRAPHY OF THE CAUCASUS}

$\mathrm{F}$ the several branches of the Russian Geographical Society, the Caucasian and the East Siberian are well known for the amount of valuable geographical work they have done during the thirty years or so of their existence. The high scientific interest connected with the exploration of the Caucasus is obvious. The scientific exploration of the Alps has revealed to us a new world; but the highlands of the Caucasus, with the high plateaux of Trauscaucasia, afford a still greater variety of geological and physico-geographical features than the Alps; besides, situated as they are on the boundary between the moist climate of the west and the dry one of the east, between the deeply-indented coasts of Europe and the deserts and plateaux of Asia, between the young civilisations of the west and the old civilisations of the east, the Caucasian bighlands afford such a variety of climatic, botanical, zoological, and ethnological features as hardly can be met with in any other country of the world. Very much remains to be done to bring these highlands within the domain of scientific knowledge. In what has been done up to the present, the Caucasian branch of the Russian Geographical Society has always had a good sbare, either by direct exploration, or by bringing to the knowledge of the scientific world such explorations as otberwise would have remained unknown in the archives of different Government offices, or by giving a scientific character to such explorations as were made for military or diplomatic purposes. Besides, the activity of the Caucasian Geographical Society is nct limited to the Caucasus. Closely connected with the General Staff of Tiflis, it extends its explora. tions to the Trans-Caspian region, to Asia Minor, and to Persia; and closely follow's the Russian military expeditions, surveyors, and diplomatists who eagerly visit these countries.

Unfortunately the publications of the Caucasian branch-the Zapiski or Memoirs, and the Izvestia or Bulletin-are but very insufficiently known abroad, Petermann's Mittheilungen being nearly the sole channel through which they are brought to the notice of the scientific world. The following summary, therefore, of the last publications of the Society will be of some use to scientific geographers. Without attempting to review all the volumes of the Memoirs and Iavestia which have appeared, we shall limit this paper to a review of the tw. last of each, the chief results of the papers contained in former volumes being already embodied in Elisée Reclus's "Géographie Universelle."

Several papers of the sixth volume of the Izvestia are devoted to the geodesy of the Caucasus and adjacent countries. During the war of 1878 a considerable amount of geodetical work was done in the province of $\mathrm{K}$ ars and in Asia Minor, and M. Kulberg gives the latitudes and longitudes determined. The longitudes of Kars, Erzerum, and Mysun were determined by means of telegraphic signals (the accuracy of this method being such as to reduce the probable error between Pulkova and Vladivostok, on the Pacific, to $\mathrm{O}^{\prime \prime} \cdot 14$, that is, to 50 yards on a distance of 7000 miles). Other Iongitudes were determined by chronometer. A trigonometrical network was extended to Erzerum, and numerous surveys were made. The longitudes of several points at Constantinople were determined with great accuracy by General Stebnitzky, as well as that of Batum by M. Kulberg.

The same volume contains also a list of latitudes and longitudes determined on the banks of the Emba and on the Mangishlak peninsula.-M. Kulberg contributes also an interesting paper on the results of determinations of lengths of the pendulum on the Caucusus, in order to determine the increase of gravity caused by the Caucasian chain. The observations were made at 
Tiflis, Elizabethpol, Dushet, Gudaur, and Vladikavkaz with the same pendulums that were used for a similar purpose in Russia and afterwards in India. It results from the observations that in all the above-named localities, the lengths of the seconds pendulum are less than the calculated ones, namely, by 0.0037 Paris lines at Batum, 0.0455 at Elizabethpol, 0.0445 at Tiflis, 0 0476 at Vladikavkaz, O'I I 7 I at Dushet, and 0'I226 at Gudaur. Thus, the geoid (or the true figure of the earth's surface, as determined by the directions of the pendulum) nearly corresponds with the spheroid on the shores of the Black Sea; it rises above it by 1587 feet at Tiflis, and by 1622 feet at Elizabethpol. It rises further north, reaching $4 \mathrm{I} 75$ feet at Dushet, and $437 \mathrm{I}$ at Gudaur, but soon falls, and has at Vladikavkaz, on the northern slope of the main chain, nearly the same height as at Tiflis, that is, 1697 feet above the spheroid.

The purely geographical papers are numerous :-M. Bakradze contributes a paper on the Batum province, - the Saatabago of antiquity, - and the basin of the Chorokh River, inclosed by mountains 10,000 feet high, and often of volcanic origin, The vegetation of the province is perhaps still more luxuriant than in other parts on the coasts of the Black Sea, where it altogether develops with a prodigious strength, owing to the great amount of rain; vines cover the trees in the coast district. But the country is thinly peopled. The old Georgian population is forgetting its language, and is disappearing from the upper parts of the basin of the Chorokh; the Lazes occupy only nineteen hamlets; the Armenians number no more than 570 houses; the Abhazes and Circassians, who have immigrated from the Cancasus, and Kurds are also scarce. -Another paper, by M. Levashoff, gives a detailed description of the mountains on the left bank of the Chorokh, between Batum and Artvin; these mountains are spurs of the AntiTaurus chain which terminates close by the Chorokh in the peak Kvahid, Io, 390 feet high. The left affluents of the Chorokh flow in narrow gorges, the bottom of which, an 1 sometimes the slopes, are occupied by hamlets of Mussulman Gurians. Each of these gorge; has its own individuality, and communication between them is very difficult. The small villages of each gorge are quite isolated from those of a neighbouring gorge. The fields of Indian corn and rice are often scratched on the small terraces on the slopes of mountains, often at a height of 3000 feet above the sea-level, and close by ruins of old small fortresses, each of which has its own legend. The tributaries of the Chorokh become wild streams after each rain, and the avalanches are dangerous enemies. The forests, which cover the mountains from top to bottom, are peopled with bears, wolves, and foxes. Furtber down, towards the sea-coast, the gorges become wider, and their bottom is covered with gardens. The Chorokh itself has a breadth of twenty-five to fifty yards, and runs with such rapidity that the kayouks, or local boats, managed with great skill through the rapids, pass the distance from Artvin to Batum (more than fifty miles) in four or five hours. - We notice also in the same volume a paper on the villayet of Trebizond, translated from the German; the letter of Mr. Gifford Palgrave on vestiges of glacial action in Northeastern Anatolia, translated from a former volume of NATURE; the account of a party who undertook to climb the Elbrouz, but stopped 3500 feet short of its summit; and a notice on Western Daghestan. - M. Chernyavsky gives a detailed description of periodical phenomena in the life of plants at Sukhum-kaleh, during the autumn, winter, and spring of the years $187 \mathbf{I}$ to r875.

M. Seidlitz contributes a note on goitre and cretinism on the Caucasus. It is spread in several valleys of the main chain, especially in the Upper Svanetia; in the valley of the Tzhenis-tzhali many cases of cretinism were noticed. Altogether the small people of Svanets, which numbers only 12,000 souls, seem to be in a state of degeneracy, and ought to have an infusion of fresh blood from without. The goitre was noticed also in adjacent parts of the upper basin of the Rion river, among the Osets. On the northern slope of the Caucasus, west of the Kazbek peak, as well as in the basin of the Kuban, the goitre was not noticed; but it is known in Western Daghestan and in the valleys of the Andian Koysou ridge. It is cured by the waters of springs containing carbonic acid. Women are more subject to this disease than men. Another disease, of hysterical character, endemic to the same locality, is worthy of notice. The men and women affected bark like dogs, and the aborigines consider it as the result of bewitching, in which the "barking grass," as the Avars say (a kind of Orchis), is used by the bewitchers. In the Anti.
Cancasus goitre was noticed in the Nakhichevan district and in the Batum province. It is always endemic, and never takes an epidemic character, as was the case in 1877 at Kokan, in Turkestan, where 9 per cent. of the soldiers and officers were seized with this disease after a year's stay at Kokan.

The ethnography of the Caucasus occupies a large place in this volume of the Izvestia. M. Zagursky contributes a note on the supposed kinship of the Osets with the Etruscans, and shows that it would be rather difficult to establish this kinship on account of a want of likeness between the Osetian language and the little we know about the language of the Etruscans.-Prof. Patkanoff contributes a valuable paper on the place occupied by the Armenian language among other Indo-European languages. He concludes that, and shows why, the question still remains open. Several linguists consider the Armenian language as decidedly belonging to the Iranian group, whilst others classify it with the European group. Lagarde distinguishes in it three elements : the Haikan, the Arkasid, and the Sassanid elements ; the two latter are Iranian, but the Haikan element belongs to a family of languages the oldest of which is the Zend. Hubschmann concludes that it occupies an intermediate place between the Iranian languages and the Slavo-Lithuanians; and Fr. Muiller, a partisan of its Iranian origin, admits that it has some kinship with the Slavo-Lithuanian languages. Prof. Patkanoff concludes that it occupies an intermediate place between these two, and is a representative of an extinct group of Indo-European languages, which formerly was spread perhaps in Asia Minor.We notice also several notes: on the dolmens of the Maykop district; on the descriptions of the first physical training given to children by different Caucasian peoples (these interesting descriptions, comprising nearly all Caucasian peoples, were sent to Moscow to Dr. Pokrovsky); on archæological discoveries in the province of Kuban, \&c.

The Izvestia contain also many interesting short notices on the scientific work done on the Caucasus by other Societies and private persons ; and bibliographical notices on different works dealing with the Caucasus. Elisée Reclus's description of the Caucasus in the "Géographie Universelle" is considered as the best that has yet appeared, and it is proposed to translate it into Russian, with notes and additions.

The Appendix contains several valuable papers, namely : a note on the Bosphorus and Constantinople, by M. Stebnitzky (with a map), containing some new information on currents in the Bosphorus and on the mean temperature at Pera, according to new observations of $\mathrm{M}$. Kumbari ( $\mathrm{I}^{\circ} \cdot 3$ Cels.); a note on the Aysors of the province of Erivan ; a note on the population of Turkish Armenia, by M. Eritsoff $(\mathrm{I}, \mathrm{I} 62,957$, out of which 214,350 are Turks, 357,577 Kurds, 498,007 Armenians, 4I,682 Kizilbashes, 25,516 Greeks, and 17,400 Aysors); and several translations.

The geodetical part is represented in the seventh volume of the Izvestia by a paper by M. Kulberg, on the influence of the oscillations of the supporting disc of the pendulum of the Russian Academy on the measured length of the seconds pendulum. The correction due to this cause was found to be equal to +0.0650 Paris lines, which correction closely corresponds to the difference between the Russian pendulum and that of Cater, which was found at Kew to be equal to 0.0056 inches, or 0.063 I Paris lines. The corrected lengths of the seconds pendulum at the abovenamed localities (at $13^{\circ}$ Réaumur, and reduced to the sea-level) would be thus: $440 \cdot 2734$ Paris lines at the Tiflis Observatory, $44^{\circ} 3279$ at Vladikavkaz, $440^{\circ} 2 \mathrm{I} 26$ at Gudaur, $440^{\circ} 2018$ at Dushet, $44^{\circ} 3172$ at Batum, and $44^{\circ} 2364$ at Elizabethpol.-A biographical notice of the late Gen. Khodzko gives an account of the immense work he performed for the triangulation of the Caucasus. He began this work in 1847 with the Anti-Caucasus, always taking for himself the most difficult parts of the work, such as the measurements on the summit of Alaghöz ( $13,43^{6}$ feet high), or of Ararat (I6,9I6 feet), 6000 feet above the snowline, and of other high summits. On June 28 , I 851 , he observed an eclipse of the sun on the summit of Galavdur, at a height of 10,380 feet, and noticed the protuberances which were doubted at that time as belonging to the atmosphere of the sun. The geodetical determination of 1386 points in Trans-Caucasia was terminated in 1854 , but that of Northern Caucasus was begun only in 1860 , and was connected with those of Russia in 1864. The accuracy of this immense work and its importance for geodesy and physical geography are well known.

The same volume contains several valuable geographical papers and maps. Among the latter the first place belongs to 
those of the frontier between Russia and Persia, from the Caspian to Babadurmaz, and of the frontier between Russia and Turkey, from the Black Sea to Ararat; both are accompanied with maps.-General Stebnitzky contributes a most valuable sketch of all that is known about the Pontian range, which follows the southern coast of the Black Sea from the Yeshil-irmak to the Chorokh.-M. Stepanoff contributes an interesting paper on the province of Kars, recently annexed to Russia ; and M. Bakradze one on the ethnography of the same province. The province consists of three different parts : the lowlands of the basin of the Olti River, covered with clay hills intersected with irrigation canals, and offering great advantages for gardening; the 5000 to 6000 feet high plateau of Kars, 50 miles long and 35 miles wide, bordered with mountains the highest of which reaches 9700 feet. It is covered with lavas and basalts, deeply cut by rivers; the mountains are devoid of wood; agriculture is carried on on this plateau, notwithstanding its great height. The third part of the province is again a plateau, 6000 to 7000 feet high, where agriculture becomes impossible, but covered with good pasture-land, and dotted with lakes. The population of the province has suffered much from wars. In the basin of the Olti and in the north-east it was formerly Georgian, who have become Mussulmans; the Kurds make one-sixth of the population. The basins of the Araxes and Kars rivers were formerly occupied by Armenians. The capital of Armenia, Ani, now in ruins, was situated here. After 1830, no less than 90,000 Armenians emigrated into Russian dominions, whilst Turks, Turcomans, Karapakhs, and Caucasian emigrants (Kabards and Osets) occupied their place, forming thus a most mixed population. Presently the Mussulmans emigrated back from the province (no less than 65,447 souls during two years), and 7 100 Russian Nonconformists have occupied their place, as well as 10,000 Greeks and about 4100 Armenians. The migration of whole populations is thus still going on in our times, as it was going on formerly after the great wars of the past. It is ea:y to foresee that the country contains most remarkable Armenian antiquities, such as churches built in the ninth and tenth centuries.

Since the year 1880 the director of the Tifiis Observatory, M. Milberg, has undertaken a series of measurements of the temperature of the ground, together witk measurements of temperature by a black-bulb thermometer suspended 1.5 metres above the ground, and M. Smirnoff analyses the results of these measurements. The blackened thermometer has given a somewhat higher average temperature for the year than the usual thermometer suspended in shade $\left(12^{\circ}{ }_{7}\right.$ Celsius, instead of $\left.\mathrm{rI}^{\circ} \cdot 6\right)$; the same was observed, as is known, in Englant. At the same time its maxima are obviously higher and its minima are lower than those of the usual thermometer in shade, its range being from $-14^{\circ} \cdot 5$ to $+42^{\circ} .9$, instead of $-12^{\circ} 0$ to $+37^{\circ} 6$; whilst the range of average temperatures of different months was $28^{\circ} \cdot 6$ instead of $27^{\circ} 5$ in the shade. The underground thermometers were placed at depths of $1,2,5, \mathbf{1 2}, 20,4 \mathrm{I}$, and 79 centimetres, and were observed, the six former every hour, and the last each three hours. Two other thermometers, placed at depths of $\mathbf{1}^{\circ} 6$ and 3.5 metres, were observed once a day. The whole series of observations is published in the Memoirs of the Cauca ian Agricultural Society, and the Izvestia give the monthly averages, as well as a résumé of the results. We shall add to this résume that the observations at Tiflis show well the retardation of seasons at a depth of 79 centimetres, the coldest and warmest months being February and August, instead of January and July. The frosts at the spot where the observations were made do not penetrate deeper than 40 centimetres.-M. Maslovsky gives some observations of temperature at Askhabad, in the Akhaltekke oasis, during the summer months; the moisture in May was but 31 to 33 per cent., falling as low as 17 per cent., and reaching sometimes 59 per cent.-M. Chernyavsky gives the Abkhaze, Mingrelian, and Georgian names of different plants.

Several papers deal with the population of the Caucasus : $M$. Zagursky has contributed a paper on the ethnographical maps of the Caucasus, and, after having sharply criticised the works of M. Rittich, recommends as the best ethnographical map of the Caucasus, that which was published by M. Seidlitz in Peter mann's Mittheilungen, and in which M. Zagursky has embodied the results of the little-known but remarkable linguistic works of the late General Uslar. Still this map leaves much to desire and ought to be accompanied by an explanatory memoir. - The much-debated question as to the number of Armenians in the Russian dominions is discussed by M. Eritsoff, who comes to the conclusion that it must be (taking into account the increase of population until I 88 I) 860,456 on the Caucasus, and 56,536 in European Russia. - M. von Eckert gives the results of anthropological measurements he has made, according to the instructions of Virchow, on 30 Adighes, 7 Ingushes, 1 I Georgians, 14 Osets, I4 Armenians, 9 Aderbijan Tartars, and 80 Little-Russians from the Government of Kharkoff. They proved to be all brachycephalic, the average indexes being $80^{\circ} 7$ for the Osets, $80^{\circ} 9$ for the Tartars, $81^{*} 9$ for the Ingushes, $82^{\circ} \circ$ for the Adighes, $82 \cdot 2$ for the Little-Russians, $83^{\circ} 3$ for the Georgians, and $86^{\circ} 5$ for the Armenians. The percentage of broad faces (chamäprosop faces, that is, those where the breadth between the cheek-bones is less than $89^{\circ} 9$ per cent. of the length of the face, measured from the upper part of the nose to the lowe:t part of the chin) is 44 for Tartars, 64 for Armenians, 71 to 77 for Osets, Georgians, and Adighes, 86 for Ingushes, and 90 for Little-Russians.

The same volume contains several notes : on the Charjui ; a list of heights in the Aderbijan ; on the Scotch colony at Kuras and many others; and a bibliographical notice, by M. Stebnitzky, of Elisée Reclus's description of the Caucasus, which is spoken of in high terms.-The Appendix contains the translation, with notes, of the memoir, by Major Trotter, on the Kurds in Asia Minor, and of the Consular Report of W. Gifford Palgrave on the provinces of Trebizond, Sivas, and Kastamuni.

The eleventh volume of the Memoirs of the Caucasian Geographical Society contain three papers by M. Petrusevitch : on the Turcomans between the Uzboy and the northern borders of Persia; on the north-eastern provinces of Khorassan; and on the south-eastern coast of the Caspian and the routes to Merv. Some of these papers are already known to English geographers; and the others probably will be translated in full. They are accompanied by a map of the Russian Trans-Caspian dominio is and of Northern Persia.

The twelfth volume of the Memoirs contains the first part of a large work, by the late General Uslar, on the ancient history of the Caucasus. It deals with the oldest traditions about the Caucasus, and is a most remarkable attempt at a scientific inquiry in to the remotest history of this country. It is accompanied by a bingraphical notice of General Uslar, by M. Zagursky, his collaborator and follower. It is certain that M. Uslar, who pursued for many years the truly scientific exploration of Caucasian languages (undertaken first by Sjögren), has done in this branch far more than anybody else. But his works-which were only lithographed in a few copies, and each of which is not only a serious study of separate languages, but also a thorough description of the nation it deals with-are very little known, and this only from the short reports that were made on them by the late Member of the Russian Academy of Sciences, M. Schiefner. The few pages in which M. Zagursky gives an account of the work of Uslar, of the methods he followed, and of the results he arrived at, ought to be translated in full, as surely they would be most welcome to all those in England who are interested in the study of ethnology. They deserve much more than a short notice.

P. K.

\section{UNIVERSITY AND EDUCATIONAL INTELLIGENCE}

OXFORD.-Prof. Moseley and Prof. Burdon Sanderson have been appointed ex officio Members of the Board of the Faculty of Natural Science.

Prof. Clifton has been elected a Member of the Hebdomadal Council in place of the late Prof. Smith.

The Professorship of Archæology and Art, founded by the late Commissioners out of the revenues of Lincoln College, has been in abeyance owing to the proposed statute not baving received the Queen's assent. The College now proposes to endow the professurship, and a statute will be promulgated at the beginning of next term, providing for a Professor of Classical Archæology and Art, "who shall lecture on the arts and manufactures, monuments, coins, and inscriptions of classical antiquity, and on Asiatic and Egyptian antiquities, or on some of those subjects."

Mr. G. A. Buckmaster, B.A., and late Natural Science Demy of Magdalen College, has, after examination, been elected to the Radcliffe Travelling Fellowship. Mr. Buckmaster also obtained the Burdett Coutts Scholarship for proficiency in geology in 1882. The Fellowship is of the annual value of $200 l$., tenable for three years. The candidate must declare that he intends to graduate in medicine in the University of Oxford, and to 